\title{
HUBUNGAN PENGGUNAAN MEDIA GAMBAR GERAK TERHADAP KEMAMPUAN MENULIS PUISI MAHASISWA PRODI PENDIDIKAN BAHASA DAN SASTRA INDONESIA FKIP UM SUMBAR
}

\author{
Megasari Martin ${ }^{1}$, Mimi Sri Irfadila ${ }^{2}$ \\ Program Studi Pendidikan Bahasa dan Sastra Indonesia \\ FKIP Universitas Muhammadiyah Sumatera Barat \\ Email : megasarimartin88@gmail.com ${ }^{1}$ mimifadila85@gmail.com²
}

\begin{abstract}
This study aims to see the relationship between learning media and students' poetry writing skills in the poetry study course. This type of research is quantitative with correlation and descriptive methods. Students who become the object of research are $3 r d$ semester students, totaling 28 people. Data collection in this study used a poetry writing ability test and a motion picture media questionnaire. The instruments used in this study were performance tests and questionnaires. In this study, students were assigned to write poetry using motion picture media. After that, students answered a questionnaire related to motion picture media. The results showed that there was a significant relationship between motion picture media and students' poetry writing skills statistically that $t$ count was greater than $t$ table or $7.514>1.701$, meaning that there was a significant relationship between motion picture media and poetry writing ability, with a confidence level of $=0.05$ and $n=30$, one-sided test; $d k=n-2=30-2=28$ so that we get $t$ table $=1.701$. The interpretation of the value of $r$ count $=0.76$ lies between it, it means that the correlation coefficient between motion picture media and the ability to write poetry is quite influential correlation between $X$ variable on the $Y$ variable, the remaining $60 \%$ is determined by other variables.
\end{abstract} Keysword: Motion picture media, poetry, writing

\begin{abstract}
Abstrak
Penelitian ini bertujuan untuk melihat hubungan antara media pembelajaran dan kemampuan menulis puisi mahasiswa pada mata kuliah kajian puisi. Jenis penelitian ini adalah kuantitatif dengan metode kolerasi dan deskriptif. Mahasiswa yang menajdi objek penelitian adalah mahasiawa semester 3 yang berjumlah 28 orang. Pengumpulan data dalam penelitian ini menggunakan tes kemampuan menulis puisi dan angket media gambar gerak. Instrumen yang digunakan dalam penelitian ini adalah tes unjuk kerja dan angket. Dalam penilian ini mahasiswa ditugaskan menulis puisi dengan penggunaan media gambar gerak. Setelah itu mahasiswa menjawab angket yang berhubungan dengan media gambar gerak. Hasil penelitian menunjukkan bahwa terdapat hubungan yang signifikan antara media gambar gerak terhadap kemampuan menulis puisi mahasiswa secara statistik bahwa $t_{\text {hitung }}$ lebih besar dari pada $t_{\text {tabel }}$ atau 7,514 > 1,701, artinya ada hubungan yang signifikan media gambar gerak dengan kemampuan menulis puisi, dengan tingkat kepercayaan $\dot{\alpha}=0,05$ dan $n=30$, uji satu pihak; $d k=n-2=30-2=28$ sehingga diperoleh $t_{\text {tabel }}=1,701$. interpretasi nilai $r$ hitung $=0,76$ terletak diantara 0,600 sampai dengan 0,800 hal itu berarti koofisien korelasi antara media gambar gerak terhadap kemampuan menulis puisi
\end{abstract}


adalah korelasi cukup berpengaruh antara variabel $X$ terhadap variabel $Y$ yaitu, sebesar $60 \%$ sisanya ditentukan variabel lain.

Kata Kunci: Media gambar gerak, puisi, menulis

\section{PENDAHULUAN}

Keterampilan menulis merupakan bagian dari 4 keterampilan berbahasa yang harus dikuasai mahasiswa. Dengan menulis, mahasiswa dapat mengungkapkan pikiran dan gagasan untuk mencapai maksud dan tujuannya. Keterampilan menulis menuntut mahasiswa untuk latihan yang cukup, teratur, dan berkesinambungan. Menulis merupakan kegiatan yang sangat penting. Melalui menulis seseorang dapat berkomunikasi dengan orang lain. Selain itu, hampir semua aktivitas belajar berkaitan dengan menulis, mulai dari menulis buku harian, esai, surat resmi, novel, artikel, cerpen (cerita pendek), menulis puisi dan kegiatan menulis lainnya. Menulis dapat dijadikan sebagai sarana untuk melatih diri untuk berkreativitas, sehingga mahasiswa dapat menuliskan ide, gagasan, pikiran, dan perasaan ke dalam berbagai jenis tulisan.

Menulis puisi adalah salah satu kemampuan yang harus dikuasai oleh mahasiswa program studi pendidikan bahasa dan sastra Indonesia pada beberapa mata kuliah sastra. Selain itu mahasiswa harus menguasai materi ini agar dapat menjadi bekal untuk menjadi seorang guru. Pada hakikatnya, puisi adalah karya sastra yang mengungkapkan perasaan penyair secara imajinatif. Wujud karya sastra tersebut muncul karena puisi merupakan karya seni yang puitis. Puitis karena membangkitkan perasaan, menarik perhatian, bahkan memancing timbulnya tanggapan pembaca. Menurut Waluyo (2011), puisi adalah karya sastra dengan bahasa yang dipadatkan, dipersingkat, dan diberi irama dengan bunyi yang padu dan pemilihan kata-kata kias (imajinatif).

Permasalahan yang sering dihadapi oleh seorang dosen pengampu mata kuliah kajian puisi adalah mahasiswa mengganggap menulis puisi adalah kegiatan yang sulit, mereka tidak mampu menulis kata-kata indah dan merasa puisi mereka tidak puitis. Upaya untuk mengatasi masalah tersebut diperlukan media pembelajaran yang tepat, media pembelajaran yang akan diupayakan yaitu media gambar gerak. Media ini dipilih karena media gambar gerak merupakan sebuah konsep belajar yang membantu dosen membimbing mahasiswa untuk lebih mudah memahami dan mengembangkan kreativitas namun tetap menyenangkan. Pembelajaran dengan media diharapkan mahasiswa mampu menghasilkan hal-hal baru serta lebih aktif mengaitkan antara materi yang diajarkan dengan situasi di dunia nyata. Media ini dianjurkan oleh penulis dalam pembelajaran menulis puisi untuk meningkatkan kreativitas dan semangat belajar siswa, agar mencapai hasil yang ditetapkan.

\section{Pembelajaran Menulis Puisi}

Menulis merupakan suatu proses kreatif yang harus mengalami suatu proses yang secara sadar dilalui dan secara sadar pula dilihat hubungan satu dengan yang lain, sehingga berakhir pada suatu tujuan yang jelas sebagai suatu proses. Menurut Semi (2009:5) menyatakan bahwa "menulis merupakan suatu proses kreatif. Sebagai suatu proses kreatif, ia harus mengalami suatu proses yang secara sadar dilalui dan secara sadar pula dilihat hubungan satu dengan yang lain, sehingga berakhir pada suatu tujuan yang jelas sebagai suatu proses”. Keterampilan 
menulis tidak dapat dilakukan secara instan namun melakukan dengan langkahlangkah yang sistematika dan teratur untuk menghasilkan tulisan yang baik.

"Puisi adalah keindahan dan suasana yang terdapat di dalam kata-kata" (Atmazaki, 2007:41). Lahirnya sebuah puisi berasal dari bahasa yang dirangkai seindah mungkin melalui kata-kata sehingga menimbulkan suasana tertentu bagi pembaca. Puisi memberikan efek estetis bagi pembaca.

Menurut Gani (2014:13-14), Puisi merupakan secara etimologi dalam bahasa Yunani kata puisi berasal dari kata poesis yang berarti penciptaan. Pencipta puisi adalah orang yang dianggap hampir menyerupai dewa atau orang yang amat suka kepada dewa-dewa. Orang yang seperti itu adalah orang yang berpenglihatan tajam, memiliki daya imajinasi tinggi, orang suci,. Orang tersebut sekaligus merupakan filsuf, negarawan, guru, dan orang yang dapat menebak kebenaran yang tersembunyi.

\section{Media Gambar Gerak Animasi}

Media pembelajaran merupakan alat atau sarana yang dibutuhkan dalam suatu proses belajar mengajar. Melalui media, interaksi yang terjadi selama proses belajar mengajar akan lebih mudah dan menarik. Selain itu sarana dalam pembelajaran dirasa juga akan mudah tercapai.

Kata media berasal dari bahasa Latin Medius yang berarti "tengah", "perantara" atau "pengantar". Hamidjojo (dalam Arsyad, 2011: 4) mengemukakan bahwa media sebagai semua bentuk perantara yang digunakan oleh manusia untuk menyampaikan atau menyebar ide, gagasan, atau pendapat sehingga sampai kepada penerima yang dituju. Media sebagai alat perantara untuk menyampaikan ide, gagasan, atau pendapat yang disampaikan seseorang kepada orang lain. Alat yang digunakan dalam menyampaikan ide, gagasan, atau pendapat dituangkan ke dalam berbagai model asalkan dimengerti oleh penerima pesan.

Kata animasi berasal dari kata animation yang berasal dari kata dasar to anime dalam kamus indonesia berarti menghidupkan. Secara umum animasi merupakan suatu kegiatan menghidupkan, menggerakkan benda mati. Suatu benda mati diberi dorongan, kekuatan, semangat dan emosi untuk menjadi hidup atau hanya berkesan hidup. Animasi adalah gambar bergerak yang terbentuk dari sekumpulan objek (gambar) yang disusun secara beraturan mengikuti alur pergerakan yang telah ditentukan pada setiap pertambahan hitungan waktu yang terjadi. Suheri (2006: 28) mengatakan bahwa gambar gerak (animasi) merupakan kumpulan gambar yang diolah sedemikian rupa sehingga menghasilkan gerakan. Salah satu keunggulan animasi adalah kemampuannya untuk menjelaskan suatu kejadian secara sistematis dalam tiap waktu perubahan. Hal ini sangat membantu dalam menjelaskan prosedur dan urutan kejadian.

Menurut Furidah (2009), "media gambar gerak (animasi) pembelajaran merupakan media yang berisi kumpulan gambar yang diolah sedemikian rupa sehingga menghasilkan gerakan seolah berkesan hidup serta menyimpan pesanpesan pembelajaran. Media gerak (animasi) pembelajaran dapat dijadikan sebagai perangkat ajar yang siap kapan pun digunakan untuk menyampaikan materi pelajaran".

Menurut Adinda dan Adjie (2011:23), gambar gerak (animasi) merupakan serangkaian gambar gerak cepat yang countine atau terus-menerus yang memiliki 
hubungan satu dengan yang lain. Gambar gerak (animasi) hanya berupa rangkaian dari potongan-potongan gambar yang di gerakkan sehingga terlihat hidup.

\section{METODOLOGI}

Jenis penelitian ini adalah kuantitatif. Arikunto (2010:12) mengatakan bahwa penelitian kuantitatif banyak dituntut menggunakan angka, mulai dari pengumpulan data, penafsiran terhadap data tersebut, serta penampilan dari hasilnya.

Metode yang digunakan dalam penelitian korelasi dan deskriptif. Metode penelitian yang digunakan untuk mencari hubungan penggunaan media dengan hasil belajar. Penelitian kolerasi bertujuan untuk menemukan ada tidaknya hubungan dan seberapa erat hubungan antara variabel tersebut. Metode penelitian korelasi bertujuan untuk menentukan hubungan antara penggunaan media gambar gerak terhadap kemampuan menulis puisi. Metode deskriptif adalah suatu metode dalam meneliti status kelompok manusia, suatu objek, satu set kondisi, suatu sistem pemikiran ataupun kelas peristiwa dalam masa mendatang. Data yang diperoleh dideskripsikan untuk menggambarkan data secara jelas dan rinci, selanjutnya dianalisis untuk menjawab rumusan masalah dengan kuantitatif.

Prosedur penelitan ini adalah (1) Tahap persiapan, pada tahap ini kegiatan yang dilakukan adalah menetapkan rencana jadwal kegiatan penelitian yang akan dilaksanakan, mempersiapkan Rancangan Pembelajaran Semester (RPS), membuat kisi-kisi soal tes kemampuan menulis puisi, mempersiapkan kuesioner atau angket, (2) Tahap Pelaksanaan, pada tahap ini penelitian dilakukan dengan menggunakan angket media gambar gerak untuk mendapatkan hasil belajar, (3) Tahap Penyelesaian, tahap ini diberikan tes akhir untuk melihat hasil belajar mahasiswa. Kemudian data diolah dan membuat kesimpulan dari hasil analisis yang digunakan.

\section{HASIL PENELITIAN DAN PEMBAHASAN}

Penelitian ini terdiri dari dua variabel. Kedua variabel yang dimaksud yaitu: (1) variabel media gambar gerak sebagai variabel terikat (X) dan (2) variabel kemampuan menulis puisi sebagai variabel bebas (Y). Data-data terkait variable $(\mathrm{X})$ media gambar gerak diperoleh dari sebaran angket yang telah diolah dalam bentuk data berupa angka-angka. Sementara data kemampuan menulis puisi variabel (Y) diperoleh dari hasil menulis puisi. Deskripsi data penelitian diperoleh dari hasil jawaban responden terhadap angket penelitian. hasil pengolahan datadata penelitian akan dianalisis dengan statistik deskriptif, yaitu mengolah data berdasarkan angket, menyusun data-data kedalam bentuk tabel atau mentabulasi data, mencari korelasi media gambar gerak (X) dengan kemampuan menulis puisi (Y), menguji hipotesis, membahas dan menginterpretasikan data-data penelitian.

\section{Data Variabel Media Gambar Gerak} a. Deskripsi Media Gambar Gerak

Media gambar gerak merupakan variabel terikat (X). data ini menjelaskan tentang bagaimana penggunaan media gambar gerak pada materi menulis puisi mahasiswa yang bersumber dari responden penelitian yang berjumlah 28 orang 
dan instrumen terdiri dari 20 item melalui indikator yang ada. Adapun skor yang diperoleh dari 28 orang responden, sebagai berikut:

Tabel 1

Jawaban Angket Media Gambar Gerak

\begin{tabular}{|c|c|c|c|c|c|c|c|c|c|c|c|c|c|c|c|c|c|c|c|c|c|}
\hline \multirow[b]{2}{*}{$\mathrm{NO}$} & \multicolumn{20}{|c|}{ ITEM SOAL } & \multirow{2}{*}{$\begin{array}{l}\text { SKOR } \\
\text { NILAI }\end{array}$} \\
\hline & 1 & 2 & 3 & 4 & 5 & 6 & 7 & 8 & 9 & 10 & 11 & 12 & 13 & 14 & 15 & 16 & 17 & 18 & 19 & 20 & \\
\hline 1 & 4 & 4 & 4 & 4 & 4 & 4 & 5 & 4 & 5 & 4 & 4 & 5 & 4 & 5 & 5 & 5 & 5 & 4 & 5 & 5 & 89 \\
\hline 2 & 5 & 5 & 5 & 5 & 5 & 5 & 5 & 5 & 5 & 5 & 5 & 5 & 5 & 5 & 5 & 5 & 5 & 5 & 5 & 5 & 100 \\
\hline 3 & 5 & 5 & 5 & 4 & 5 & 4 & 5 & 5 & 5 & 4 & 4 & 4 & 5 & 5 & 4 & 5 & 5 & 5 & 4 & 4 & 92 \\
\hline 4 & 3 & 3 & 4 & 4 & 4 & 3 & 3 & 4 & 3 & 4 & 4 & 4 & 3 & 4 & 5 & 5 & 5 & 5 & 5 & 5 & 80 \\
\hline 5 & 5 & 4 & 4 & 5 & 5 & 4 & 4 & 4 & 5 & 5 & 5 & 4 & 5 & 4 & 5 & 4 & 4 & 5 & 4 & 4 & 90 \\
\hline 6 & 5 & 5 & 5 & 5 & 4 & 5 & 5 & 5 & 4 & 5 & 4 & 4 & 5 & 4 & 5 & 4 & 4 & 5 & 4 & 5 & 92 \\
\hline 7 & 5 & 4 & 5 & 5 & 4 & 5 & 3 & 4 & 5 & 4 & 5 & 3 & 4 & 5 & 5 & 5 & 5 & 4 & 5 & 5 & 90 \\
\hline 8 & 4 & 3 & 3 & 4 & 5 & 5 & 5 & 5 & 5 & 5 & 5 & 5 & 5 & 4 & 4 & 5 & 4 & 4 & 4 & 5 & 89 \\
\hline 9 & 5 & 4 & 5 & 4 & 5 & 4 & 5 & 4 & 4 & 5 & 5 & 5 & 4 & 5 & 4 & 4 & 4 & 5 & 5 & 4 & 90 \\
\hline 10 & 5 & 5 & 4 & 4 & 2 & 4 & 3 & 3 & 5 & 3 & 4 & 4 & 3 & 4 & 3 & 3 & 4 & 3 & 4 & 3 & 73 \\
\hline 11 & 4 & 4 & 4 & 5 & 5 & 5 & 4 & 4 & 4 & 3 & 4 & 3 & 2 & 2 & 3 & 3 & 4 & 4 & 4 & 4 & 75 \\
\hline 12 & 3 & 4 & 5 & 5 & 5 & 3 & 3 & 4 & 5 & 4 & 3 & 3 & 2 & 2 & 3 & 4 & 3 & 3 & 2 & 2 & 68 \\
\hline 13 & 5 & 5 & 5 & 5 & 5 & 5 & 5 & 5 & 5 & 5 & 5 & 5 & 5 & 5 & 5 & 5 & 5 & 5 & 5 & 5 & 100 \\
\hline 14 & 4 & 4 & 4 & 4 & 4 & 4 & 4 & 4 & 4 & 4 & 4 & 4 & 5 & 5 & 5 & 5 & 5 & 5 & 5 & 5 & 88 \\
\hline 15 & 3 & 4 & 3 & 4 & 3 & 5 & 4 & 3 & 2 & 1 & 3 & 4 & 2 & 1 & 4 & 3 & 3 & 3 & 2 & 4 & 61 \\
\hline 16 & 5 & 5 & 5 & 5 & 5 & 5 & 5 & 5 & 5 & 5 & 4 & 5 & 5 & 5 & 5 & 5 & 5 & 5 & 4 & 4 & 97 \\
\hline 17 & 5 & 5 & 5 & 4 & 4 & 5 & 5 & 4 & 4 & 4 & 5 & 4 & 4 & 4 & 5 & 5 & 5 & 5 & 5 & 5 & 92 \\
\hline 18 & 5 & 5 & 4 & 5 & 5 & 4 & 5 & 5 & 5 & 5 & 5 & 5 & 5 & 4 & 5 & 5 & 5 & 5 & 4 & 5 & 96 \\
\hline 19 & 3 & 3 & 3 & 3 & 3 & 4 & 4 & 3 & 4 & 4 & 5 & 4 & 4 & 4 & 4 & 4 & 4 & 4 & 5 & 4 & 76 \\
\hline 20 & 5 & 4 & 4 & 3 & 3 & 3 & 3 & 4 & 3 & 4 & 5 & 4 & 4 & 3 & 3 & 4 & 5 & 4 & 3 & 5 & 76 \\
\hline 21 & 5 & 4 & 5 & 5 & 5 & 3 & 2 & 5 & 5 & 5 & 5 & 4 & 4 & 3 & 3 & 4 & 5 & 4 & 4 & 5 & 85 \\
\hline 22 & 5 & 5 & 5 & 5 & 5 & 5 & 5 & 5 & 5 & 5 & 5 & 5 & 5 & 5 & 5 & 5 & 5 & 5 & 5 & 5 & 100 \\
\hline 23 & 5 & 5 & 5 & 5 & 5 & 5 & 5 & 5 & 5 & 5 & 5 & 5 & 5 & 5 & 5 & 5 & 5 & 5 & 5 & 5 & 100 \\
\hline 24 & 5 & 5 & 5 & 5 & 5 & 4 & 5 & 5 & 5 & 5 & 5 & 5 & 5 & 5 & 5 & 5 & 5 & 5 & 5 & 5 & 99 \\
\hline 25 & 4 & 4 & 3 & 5 & 4 & 3 & 3 & 3 & 3 & 5 & 4 & 4 & 3 & 4 & 5 & 3 & 5 & 5 & 4 & 3 & 72 \\
\hline 26 & 3 & 5 & 5 & 4 & 5 & 4 & 4 & 3 & 4 & 3 & 5 & 3 & 3 & 3 & 4 & 4 & 4 & 4 & 4 & 5 & 79 \\
\hline 27 & 3 & 3 & 4 & 5 & 4 & 4 & 4 & 3 & 3 & 3 & 5 & 5 & 4 & 3 & 3 & 4 & 5 & 5 & 4 & 3 & 77 \\
\hline 28 & 5 & 5 & 5 & 3 & 4 & 5 & 4 & 3 & 5 & 4 & 4 & 4 & 4 & 3 & 4 & 5 & 5 & 3 & 3 & 3 & 81 \\
\hline
\end{tabular}

(Sumber: Olahan Data jawaban angeket media gambar gerak)

\section{b. Validitas Angket Media Gambar Gerak}

Berdasarkan perhitungan validitas butir angket maka diperoleh validitas setiap butir angket media gambar gerak dapat disimpulkan bahwa, $\mathrm{t}$ hitung $=2,741$ dan $\mathrm{t}$ tabel $\mathrm{n}-2$ atau 30-2= 28 dan dinyatakan 1,701 artinya thitung $\geq$ ttabel dan soal angket no 1 dinyatakan valid. Untuk soal angket no 2 sampai no 20 dilakukan dengan cara yang sama maka diperoleh data sebagai berikut:

Tabel 2 
Validitas Angket Media Gambar Gerak

\begin{tabular}{|c|c|c|c|c|}
\hline No & Rxy & $\mathrm{t}$ hitung & $\mathrm{t}$ tabel & Keterangan \\
\hline 1 & 0,46 & 2,741 & 1,701 & VALID \\
\hline 2 & 0,92 & 12,418 & 1,701 & VALID \\
\hline 3 & 0,73 & 5,650 & 1,701 & VALID \\
\hline 4 & 0,53 & 3,307 & 1,701 & VALID \\
\hline 5 & 0,86 & 8,915 & 1,701 & VALID \\
\hline 6 & 0,65 & 4,525 & 1,701 & VALID \\
\hline 7 & 1,13 & 5,978 & 1,701 & VALID \\
\hline 8 & 0,94 & 14,575 & 1,701 & VALID \\
\hline 9 & 0,10 & 0,532 & 1,701 & TIDAK VALID \\
\hline 10 & 0,74 & 5,820 & 1,701 & VALID \\
\hline 11 & 0,20 & 1,080 & 1,701 & TIDAK VALID \\
\hline 12 & 1,03 & 5,449 & 1,701 & VALID \\
\hline 13 & 1,30 & 6,877 & 1,701 & VALID \\
\hline 14 & 1,43 & 7,565 & 1,701 & VALID \\
\hline 15 & 0,85 & 8,536 & 1,701 & VALID \\
\hline 16 & 0,66 & 4,647 & 1,701 & VALID \\
\hline 17 & 0,86 & 8,915 & 1,701 & VALID \\
\hline 18 & 0,52 & 3,220 & 1,701 & VALID \\
\hline 19 & 1,03 & 5,449 & 1,701 & VALID \\
\hline 20 & 0,42 & 2,448 & 1,701 & VALID \\
\hline
\end{tabular}

(Sumber: Olahan data validitas angket media gambar gerak)

Berdasarkan tabel tersebut diperoleh data bahwa, dari 20 butir angket media gambar gerak 18 butir dengan keterangan valid yaitu soal angket no 1, 2, 3, $4,5,6,7,8,10,12,13,14,15,16,17,18,19$ dan 20. Dan terdapat 2 buah soal angket tidak valid yaitu terdapat pada no 9 dan 11. Angket yang berketerangan valid berarti cocok untuk digunakan, sedangkan yang berketerangan tidak valid berarti tidak cocok untuk digunakan. Angket yang valid menentukan keterkaitan penggunaan media gambar gerak terhadap kemampuan menulis puisi mahasiswa.

\section{Data Variabel kemampuan menulis puisi}

Kemampuan menulis puisi merupakan variabel terikat (Y). Data ini menjelaskan tentang bagaimana kemampuan menulis puisi siswa yang bersumber dari responden penelitian dengan jumlah 28 orang. Adapun nilai yang diperoleh dari 28 orang responden, sebagai berikut:

Tabel 3

Hasil Tes Akhir Menulis Puisi

\begin{tabular}{|c|l|c|c|c|c|}
\hline \multirow{2}{*}{ NO } & NAMA & \multicolumn{3}{|c|}{$\begin{array}{c}\text { Perolehan Skor/ } \\
\text { Indikator }\end{array}$} & \multirow{2}{*}{ NILAI } \\
\cline { 3 - 5 } & & I & II & III & NILA \\
\hline 1 & Subjek 1 & 3 & 1 & 3 & 78 \\
\hline 2 & Subjek 2 & 3 & 3 & 3 & 100 \\
\hline 3 & Subjek 3 & 2 & 2 & 3 & 78 \\
\hline
\end{tabular}




\begin{tabular}{|c|c|c|c|c|c|}
\hline 4 & Subjek 4 & 3 & 3 & 3 & 100 \\
\hline 5 & Subjek 5 & 2 & 3 & 3 & 89 \\
\hline 6 & Subjek 6 & 2 & 2 & 2 & 67 \\
\hline 7 & Subjek 7 & 3 & 2 & 3 & 89 \\
\hline 8 & Subjek 8 & 2 & 3 & 3 & 89 \\
\hline 9 & Subjek 9 & 3 & 2 & 2 & 78 \\
\hline 10 & Subjek 10 & 3 & 2 & 2 & 78 \\
\hline 11 & Subjek 11 & 2 & 2 & 3 & 78 \\
\hline 12 & Subjek 12 & 3 & 3 & 3 & 100 \\
\hline 13 & Subjek 13 & 2 & 3 & 3 & 89 \\
\hline 14 & Subjek 14 & 3 & 3 & 3 & 100 \\
\hline 15 & Subjek 15 & 3 & 2 & 2 & 78 \\
\hline 16 & Subjek 16 & 2 & 2 & 3 & 78 \\
\hline 17 & Subjek 17 & 2 & 2 & 2 & 67 \\
\hline 18 & Subjek 18 & 2 & 2 & 3 & 78 \\
\hline 19 & Subjek 19 & 3 & 2 & 2 & 78 \\
\hline 20 & Subjek 20 & 2 & 3 & 3 & 89 \\
\hline 21 & Subjek 21 & 3 & 3 & 3 & 100 \\
\hline 22 & Subjek 22 & 3 & 2 & 2 & 78 \\
\hline 23 & Subjek 23 & 3 & 2 & 3 & 89 \\
\hline 24 & Subjek 24 & 2 & 3 & 3 & 89 \\
\hline 25 & Subjek 25 & 2 & 2 & 3 & 78 \\
\hline 26 & Subjek 26 & 2 & 3 & 2 & 78 \\
\hline 27 & Subjek 27 & 3 & 2 & 2 & 78 \\
\hline 28 & Subjek 28 & 2 & 3 & 3 & 89 \\
\hline \multicolumn{2}{|c|}{ Rata-rata } & & & & 84,6 \\
\hline \multicolumn{2}{|c|}{ Presentase Ketuntasan Belajar } & & & & 87,53 \\
\hline
\end{tabular}

(Sumber: Olahan Data Tes Akhir Menulis Puisi)

Keterangan : Indikotor I diksi atau pilihan kata yang sesuai

: Indikator II pengimajian atau citraan

: Indikator III kata konkret yang membangkit imajinasi

Penggunaan media gambar gerak yang dilaksanakan pada pemebelajaran menulis puisi memberikan kontribusi terhadap variebel $\mathrm{Y}$ sebesar $60 \%$ dan sisanya ditentukan oleh variabel lainnya. Uji hipotesis yang dilakukan dapat ditarik kesimpulan penelitian bahwa t hitung lebih besar dari t tabel atau 7,514 > 1,701 maka H0 ditolak, artinya ada hubungan yang signifikan antara media gambar gerak dengan kemampuan menulis puisi mahasiswa pendidikan bahasa dan sastra Indonesia FKIP UM Sumbar. Dengan koofesian korelasi interpretasi nilai $r=0,76$ terletak diantara $\quad 0,600$ sampai dengan 0,800 hal itu berarti koofisien korelasi antara media gambar gerak terhadap kemampuan menulis puisi adalah Korelasi Cukup. 


\section{KESIMPULAN, IMPLIKASI DAN SARAN}

Berdasarkan hasil penelitian diperoleh gambaran tentang hubungan penggunaan media gambar gerak terhadap kemampuan menulis puisi mahasiswa pendidikan bahasa dan sastra Indonesia FKIP UM Sumbar. Secara umum, penggunaan angket media gambar sebanyak 20 butir soal, dengan keterang valid 18 butir soal, dan berketerangan tidak valid 2 butir soal, angket yang valid menentukan keterkaitan penggunaan media gambar gerak terhadap kemampuan menulis puisi mahasiswa. Untuk menulis puisi mahasiswa sudah mencapai nilai tuntas. Kemampuan tersebut dibuktikan dengan rata-rata keseluruhan dari indikator yang dinilai yaitu presentase menulis puisi mahasiswa pendidikan bahasa dan sastra Indonesia FKIP UM Sumbar adalah 87,53.

Uji hipotesis yang dilakukan di atas dapat ditarik kesimpulan penelitian bahwa t hitung lebih besar dari t tabel atau 7,514 > 1,701 maka H0 ditolak, artinya ada hubungan yang signifikan antara media gambar gerak dengan kemampuan menulis mahasiswa pendidikan bahasa dan sastra Indonesia FKIP UM Sumbar. Dengan koofesian korelasi interpretasi nilai $r=0,76$ terletak diantara 0,600 sampai dengan 0,800 hal itu berarti koofisien korelasi antara media gambar gerak terhadap kemampuan menulis puisi adalah Korelasi Cukup.

Berdasarkan penelitian ini dapat disarankan bahwa pembelajaran dengan media gerak sangat memotivasi mahasiswa untuk menulis puisi. Tidak hanya dalam mata kuliah sastra namun dapat dicobakan dengan mata kuliah lain. Peneliti yang ingin menerapkan media gambar gerak diharapkan mengikuti langkahlangkah media ini dengan benar agar mendapat hasil yang optimal. Untuk peneliti lain penelitian ini dapat sebagai referensi untuk penelitian selanjutnya terkait dengan penelitian korelasi atau penelitian hubungan sebab akibat.

\section{DAFTAR KEPUSTAKAAN}

Adawiyah, Siti Robiah dkk. 2018. Pembelajaran Menulis Puisi dengan Teknik Onomatope di MA Tanjungjaya. Jurnal Parole (Jurnal Pendidikan Bahasa Dan Sastra Indonesia) Volume I (897-904)P - ISSN 2614-624X.E - ISSN 2614-6231. https://dosen.ikipsiliwangi.ac.id/wpcontent/uploads/sites/6/2019/07/parole-teknik-onomatope.pdf .

Adinda dan Adjie. 2011. B1 3D Studio Max $9+c d$. Flim Animasi 2D Berbasis 3D Menggunakan Teknik Cell Shading Berjudul The Postman Stir,. 6.Tugas Akhir. Surabaya: Stikom.

Arikunto. 2010. Prosedur Penelitian suatu pendekatan praktik edisi revisi VII. Jakarta: Rineka Cipta.

Arsyad, Azhar. 2011. Media Pembelajaran. Jakarta: Grafindo.

Atmazaki. 2007. Ilmu Satra Teori dan Terapan. Padang: UNP Press.

Furidah. 2009. Pengertian Media Pembelajaran. (Online), http://kamriantiramli.wordpress.com/2011/02/28/pengaruh-pengaruhmedia-animasi-sebagai-strategi-pembelajaran-aktif-pada-konsepmetabolisme-di-kelas-xii-man-negeri-2-binjail. Diakses tanggal 5 februari 2014 jam 15.10.

Gani, Erizal. 2014. Kiat Pembacaan Puisi: Teori dan Terapan. Bandung: Reka Cipta.

Keraf, Gorys. (2008). Diksi dan Gaya Bahasa. Jakarta: Gramedia Pustaka Utama 
Nurjanah, E., Lestari, S., \& Firmansyah, D. (2018). Tinjauan Semiotika Puisi Ibu Indonesia Karya Sukmawati Soekarnoputri. Parole (Jurnal Pendidikan Bahasa Dan Sastra Indonesia), 1(3), 283-290. ttps://doi.org/10.22460/P.V1I3P\%P.658

Semi, M. Atar. 2009. Menulis Efektif. Padang: UNP Press.

Tarigan, H. G. (2008). Menulis sebagai suatu keterampilan berbahsa. Bandung: PT Angkasa.

Waluyo, H.J. (2011). Apresiasi Puisi. Jakarta: Gramedia Pustaka Utama

Wardoyo, S. (2013). Teknik Menulis Puisi. Yogyakarta: Graha Ilmu. 